\title{
Using Nano- and Micro-Titanium Dioxide (TiO2) in Concrete to Reduce Air Pollution
}

Hala N. Elia ${ }^{1}$, Anindya Ghosh ${ }^{2}$, Amin k. Akhnoukh ${ }^{3}$ and Zeid A. Nima ${ }^{4}$

${ }^{1}$ Department of Systems Engineering, George W. Donaghey College of Engineering and Information Technology, University of Arkansas at Little Rock, Little Rock, AR, 72204, USA ${ }^{2}$ Department of Chemistry, College of Arts, Letters and Sciences, University of Arkansas at Little Rock, AR, 72204, USA

${ }^{3}$ Department of Construction Management, College of Engineering and Technology, East Carolina University, Greenville, NC 27858-4353, USA

${ }^{4}$ Center for Integrative Nanotechnology Sciences, University of Arkansas at Little Rock, AR, 72204, USA

\begin{abstract}
A crucial element in construction, tunnels, roads, and more, concrete has become one of the most important materials in the world. At the same time, air pollution, particularly in crowded cities, is increasing, mainly due to industrial activity and transportation. Therefore, one possible approach to reduce pollution is to use "smart" construction materials, particularly those that incorporate photocatalytic active nano- and micro-size structures into concrete. Incorporating titanium dioxide $\left(\mathrm{TiO}_{2}\right)$ in roads and pavements could degrade and reduce various pollutants under ultraviolet sun radiation. $\mathrm{TiO}_{2}$-infused concrete would also maintain its optical characteristics for far longer than traditional concrete mix. This study evaluated the ability of concrete containing nano- and micro- $\mathrm{TiO}_{2}$ to degrade organic molecules, as assessed by the concrete's ability to degrade Rhodamine $\mathrm{B}$ dye. The amount of nano- and micro- $\mathrm{TiO}_{2}$ in the concrete samples was $3,6,9,12$, and $15 \%$ of the cement composition. The resulting concrete blocks were exposed to sunlight for $24,48,72$, and 96 hours. Both the nano- and micro- $\mathrm{TiO}_{2}$ significantly degraded the Rhodamine $\mathrm{B}$ dye, demonstrating the potential of this approach to benefit the smart construction industry and, as a result, fight certain types of air pollution.
\end{abstract}

Keywords: Environmental; Nanotechnology; Nanoparticle; Microparticles; Titanium dioxide; Concrete

\section{Introduction}

Concrete is a vital building block of modern life, used in homes, roads, airports, skyscrapers, and more. In fact, it is the most common synthetic structural material in the world, with almost 3 tons utilized per person every year [1]. The name itself means "to grow together" in Latin, referring to the process of mixing all of concrete's components to create a solid from a liquid [2].

Unfortunately, pollution is another fact of modern life. The Environmental Protection Agency tracks emissions of the most hazardous air pollutants that negatively impact human health and the environment; these pollutants include carbon monoxide, sulfur dioxide, particulate matter, volatile organic compounds (VOC), nitrogen oxides (NOx), and lead. All these air pollutants are increasing worldwide, particularly in crowded cities. As a result, certain health problems are also increasing, such as cardiovascular disease and respiratory issues. Pollution can also affect the nervous system in a variety of ways (i.e., learning, memory, and behavior; IQ loss) and contribute to cancer and premature death [3]. Automobile emissions are a primary source of air pollution; Figure 1 shows other common sources.

A possible solution to the international pollution problem is the use of "smart" concrete that is infused with materials that can break down air pollutants and render them harmless. One such material is titanium dioxide $\left(\mathrm{TiO}_{2}\right)$, which is classified as Generally Recognized as Safe (GRAS) by the U.S. Food and Drug Administration [4,5]. Around 4 million tons of $\mathrm{TiO}_{2}$ are utilized annually in materials such as paints, plastics, food, papers, inks, medicines, toothpastes, and sunscreens [6]. Three forms of $\mathrm{TiO}_{2}$ particles exist: rutile, anatase, and brookite, with anatase particles becoming rutile at high temperatures [7]. $\mathrm{TiO}_{2}$ is able to help fight pollution as an additive to concrete, with anatase $\mathrm{TiO}_{2}$ having the best photoactivity [8]. When heat and light hit the concrete's surface, $\mathrm{TiO}_{2}$ uses this energy to break down certain pollutants, such as NOx and VOCs, changing them from the harmful phase to the harmless phase, as shown in Figure 2 [7].
In this study, we infused nanoscale and microscale $\mathrm{TiO}_{2}$ into cement to make the resulting concrete photocatalytic. We then measured the efficiency of the photocatalytic concrete to remove organic pollutants, based on their removal of Rhodamine B dye.

\section{Background}

Because automobiles are a major source of air pollution, treating air impurities at the site of traffic makes logical sense. To do so, photocatalytic materials can be integrated into the surface of roads, buildings, and pavement. When activated by sunlight, these photocatalytic materials oxidize different kinds of pollutants, which are then precipitated on nearby surfaces and removed by rain or cleaning with water [8-10]. For example, studies have shown that a thin coating containing $\mathrm{TiO}_{2}$ on a surface near the source of contamination can eliminate a large amount of NOx and VOC pollutants from the atmosphere. Such a coating would be a non-invasive, affordable method to protect buildings against the effects of biological pollutants and smog. In one study, a single square meter of $\mathrm{TiO}_{2}$ coating under sunlight was able to remove $\mathrm{NO}_{\mathrm{x}}$ and VOC from about $200 \mathrm{~m}^{3}$ and $60 \mathrm{~m}^{3}$ of air per day, respectively $[11,12]$. A photocatalytic $\mathrm{TiO}_{2}-\mathrm{SiO}_{2}$ nanocomposite system was designed to coat buildings in order to combat the deterioration caused by air pollutants. The photocatalytic activity of the composite was analyzed by measuring its self-cleaning ability, using Methylene blue, when coated on portions of a real outdoor concrete wall. After a year, the researchers studied the color degradation

*Corresponding author: Zeid A. Nima, Center for Integrative Nanotechnology Sciences, University of Arkansas at Little Rock, AR, 72204, USA, Tel (501) 6837678, E-mail: zanima@ualr.edu

Received: May 04, 2018; Accepted: May 31, 2018; Published: June 05, 2018

Citation: Elia HN, Ghosh A, Akhnoukh AK, Nima ZA (2018) Using Nano- and Micro-Titanium Dioxide $\left(\mathrm{TiO}_{2}\right)$ in Concrete to Reduce Air Pollution. J Nanomed Nanotechnol 9: 505. doi: 10.4172/2157-7439.1000505

Copyright: @ 2018 Elia HN, et al. This is an open-access article distributed under the terms of the Creative Commons Attribution License, which permits unrestricted use, distribution, and reproduction in any medium, provided the original author and source are credited. 
Citation: Elia HN, Ghosh A, Akhnoukh AK, Nima ZA (2018) Using Nano- and Micro-Titanium Dioxide $\left(\mathrm{TiO}_{2}\right)$ in Concrete to Reduce Air Pollution. J Nanomed Nanotechnol 9: 505. doi: 10.4172/2157-7439.1000505

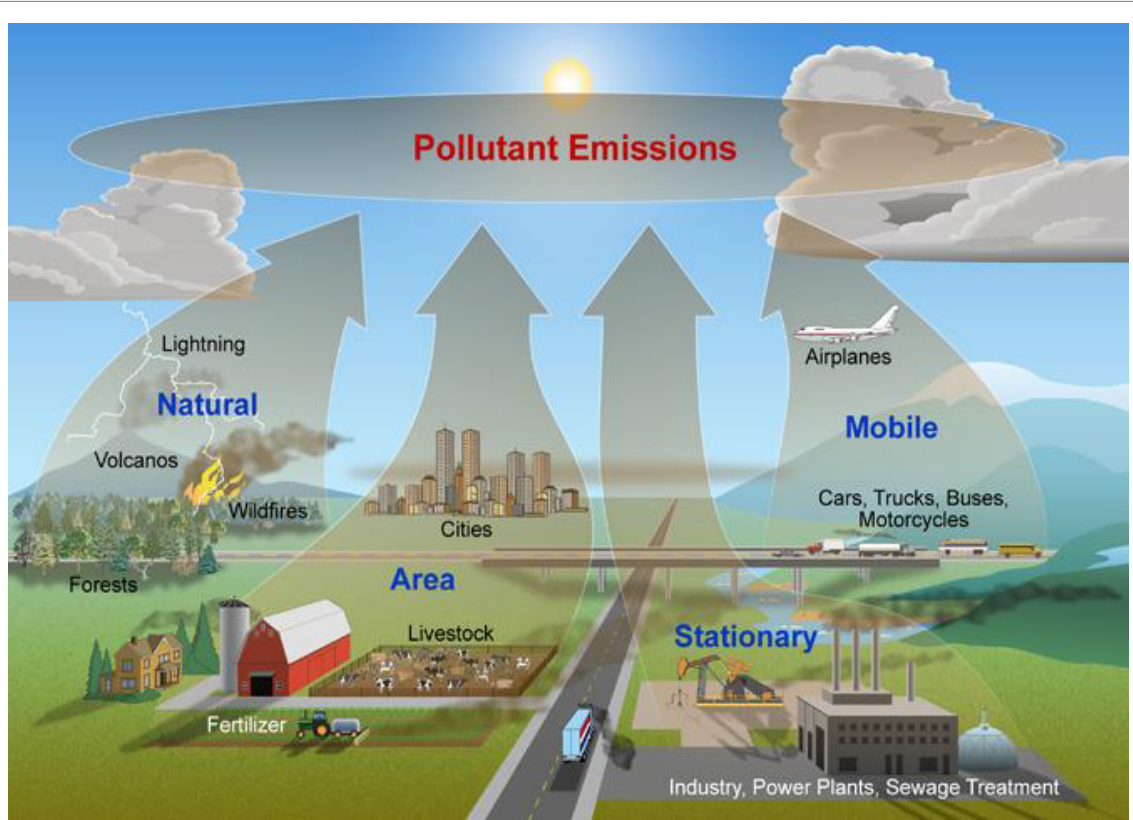

Figure 1: Sources of air pollution [4]

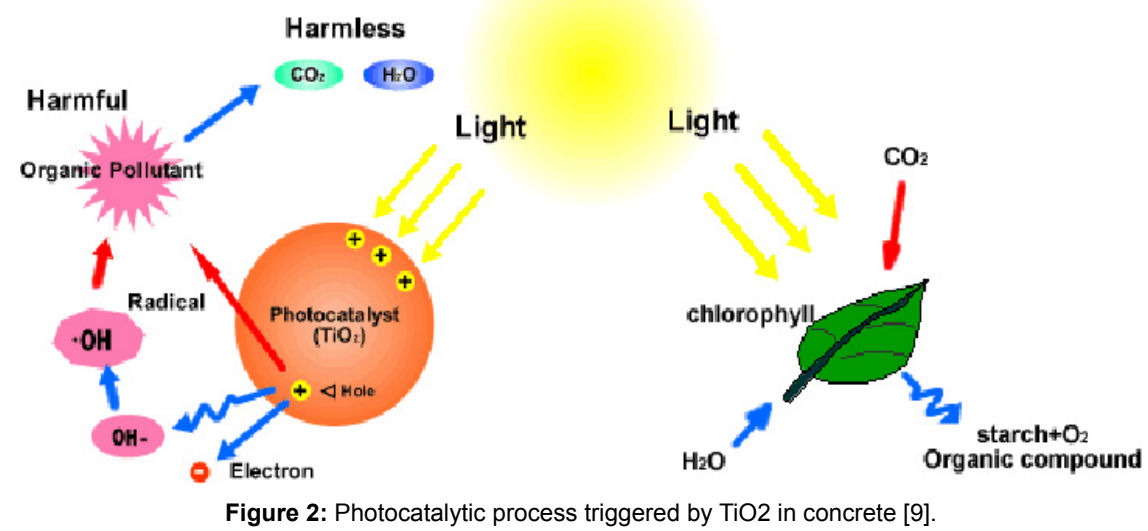

and found reasonable results. They also studied the system's ability to protect the concrete from bacterial organisms and found it to have had a good antibacterial effect against most of the tested organisms.

In another project, Beeldens integrated $\mathrm{TiO}_{2}$ into concrete pavement blocks to test its use as a photocatalytic for air purification, measured in terms of $\mathrm{NO}_{\mathrm{x}}$ reduction. In this study, the inlet concentration of $\mathrm{NO}$ was equal to $1 \mathrm{ppm}$. When the UV light was turned on, the concentration dropped by approximately $40 \%$. After 5 hours of UV light exposure, both the NO and the light were turned off for 30 minutes. The $\mathrm{NO}_{\mathrm{x}}$ concentration was measured and had notably decreased. The final measurements varied based on the size of the exposed surface, the material itself, the concentration of NO, the light intensity, the flow rate, and the air temperature. The best results were seen under low relative humidity, high temperature $\left(>25^{\circ} \mathrm{C}\right)$, long contact time, and high light intensities. These are the conditions seen on hot, sunny days without wind-the same conditions that foster a high risk of smog formation [10].
Kumar et al. compared doped $\mathrm{TiO}_{2}$ with $0.2 \%$ Ag or $2 \%$ Ag to non-doped $\mathrm{TiO}_{2}$ when both samples were integrated into white cement. Their goal was to produce a concrete that self-cleans under sunlight and UV light. The cement containing doped $\mathrm{TiO}_{2}$ showed better degradation efficiency than the non-doped cement in both sunlight and UV light. $\mathrm{TiO}_{2}$-cement slabs with $2 \% \mathrm{Ag}$ displayed the most efficient color degradation compared with the other samples. Therefore, they concluded that adding $\mathrm{TiO}_{2}$ to white cement is an excellent method to produce self-cleaning cement, with the surface only needing water (in the form of rain or humidity), sunlight, and atmospheric oxygen to self-clean [13]. However, Dylla et al. found that higher air flows lead to lower NO removal efficiency because the decreased contact of the pollutants with the concrete does not allow enough time for them to be absorbed and removed by the photocatalytic compound [14]. Zhang et al. tested different dosages of $\mathrm{TiO}_{2}$, between $1 \%$ and $6 \%$, in traditional Portland cement mortar to study $\mathrm{TiO}_{2}$ 's self-cleaning ability; $50 \%$ slag as cement replacement was included for comparison. The specimens with $1 \% \mathrm{TiO}_{2}$ showed 
Citation: Elia HN, Ghosh A, Akhnoukh AK, Nima ZA (2018) Using Nano- and Micro-Titanium Dioxide $\left(\mathrm{TiO}_{2}\right)$ in Concrete to Reduce Air Pollution. J Nanomed Nanotechnol 9: 505. doi: 10.4172/2157-7439.1000505

Page 3 of 5

good self-cleaning and faster rates of recovery to the original color. When the $\mathrm{TiO}_{2}$ dosage was increased to $2 \%$, the rate of color recovery also increased. In general, the slag mortars showed slightly lower or similar rates of color recovery-less efficient self-cleaning-than the Portland cement mortars [15].

Hassan et al. studied three different methods to apply $\mathrm{TiO}_{2}$ to concrete. The first method involved applying thin coatings of $\mathrm{TiO}_{2}-$ $3 \%$ and $5 \%$-to the concrete surface. In the second method, a hardened concrete surface was treated with water-based $\mathrm{TiO}_{2}$. Finally, the third method consisted of sprinkling nano-sized $\mathrm{TiO}_{2}$ particles (3\% and 5\%) on the surface of fresh concrete before it hardened. The results showed that the $5 \% \mathrm{TiO}_{2}$ coating and the water-based $\mathrm{TiO}_{2}$ removed $\mathrm{NO}_{\mathrm{x}}$ from the air the best. The samples treated with the water-based $\mathrm{TiO}_{2}$ product showed the highest NO removal efficiency [16].

\section{Experimental Details}

\section{Materials}

Cement: In this research, type I Portland cement obtained from Ash Grove Cement Company was utilized in all mixtures to prevent variation in results. The cement properties are listed in Table 1.

Coarse aggregate: The coarse aggregate was obtained from Webco Mining, Inc. It complies with the grading requirements of ASTM C-136. It has an absorption capacity of $1.2 \%$ and specific gravity of 2.57 . Table 2 shows the course aggregate gradation.

Fine aggregate: Fine aggregate (sand) was purchased from Jeffery Sand Co. It has a specific gravity of 2.62 and absorption capacity of $0.48 \%$ and complies with ASTM C-33, as presented in Table 3.

Water: Clean, fresh drinking tap water, free from impurities, was used in all mixes.

TiO$_{2}$ : Table 4 presents the characteristics of the nano- and microscaleTiO 2 . The microscale $\mathrm{TiO}_{2}$ was obtained from Crystal Co., and the nanoscale $\mathrm{TiO}_{2}$ was obtained from Sigma Aldrich.

Rhodamin B dye: 0.01 millimoles of Rhodamine B dye was used to represent organic pollutants.

\begin{tabular}{|c|c|}
\hline Component & Percent by weight \\
\hline $\mathrm{SiO}_{2}$ & $20.08 \%$ \\
\hline $\mathrm{Al}_{2} \mathrm{O}_{3}$ & $4.65 \%$ \\
\hline $\mathrm{Fe}_{2} \mathrm{O}_{3}$ & $4.11 \%$ \\
\hline $\mathrm{CaO}$ & $63.63 \%$ \\
\hline $\mathrm{MgO}$ & $0.94 \%$ \\
\hline $\mathrm{SO}_{3}$ & $3.19 \%$ \\
\hline $\mathrm{Na}_{2} \mathrm{O}$ & $0.16 \%$ \\
\hline $\mathrm{K}_{2} \mathrm{O}$ & $0.54 \%$ \\
\hline Limestone & $2.7 \%$ \\
\hline
\end{tabular}

Table 1: Portland cement properties (Information provided by the Ash Grove Cement Company).

\begin{tabular}{|c|c|}
\hline Sieve Size & \% Passing as tested \\
\hline 1.5 inch $(38 \mathrm{~mm})$ & 100 \\
\hline $3 / 4$ inch $(19.05 \mathrm{~mm})$ & 95.1 \\
\hline $3 / 8$ inch $(9.5 \mathrm{~mm})$ & 28.55 \\
\hline$\# 4(4.75 \mathrm{~mm})$ & 5.2 \\
\hline$\# 8(2.36 \mathrm{~mm})$ & 0.4 \\
\hline$\# 16(1.18 \mathrm{~mm})$ & 0.3 \\
\hline
\end{tabular}

Table 2: Coarse aggregate gradation (Information provided by Webco Mining, Inc).

\section{Methods}

Traditional concrete mix contains cement, fine and coarse aggregates, and water. In this work, different concentrations of titanium dioxide $(3,6,9,12$, or $15 \%(\mathrm{w} / \mathrm{w})$ of the cement composition; 3 samples for each concentration) were also added to the mix. In real situations, this kind of modified concrete mix would be applied as the top layer of concrete, making up about $10 \%$ of the thickness of the concrete, because only the surface is involved in the photocatalytic process. Two sizes of $\mathrm{TiO}_{2}$ were utilized, nanoscale and microscale, both with the same crystal structure (anatase). Table 5 lists the contents of the $\mathrm{TiO}_{2}$ infused concrete mixes used in this work.

After the concrete samples were prepared, $0.1 \mathrm{ml}$ of $(10 \mathrm{mM})$ Rhodamine B were applied on top to represent organic pollutants. Next, the samples were put under sunlight to mimic real conditions, and the color intensity degradation was measured after $24,48,72$, and 96 hours. All samples were put out together to avoid unwanted differences between them. Image ${ }^{\circledR}$ software was used to analyze color removal efficiency to identify the optimal dose and size of $\mathrm{TiO}_{2}$.

\section{Results}

Both the nano- and microscaleTiO ${ }_{2}$ degraded the color on top of the concrete, but the micro- $\mathrm{TiO}_{2}$ performed better than the nano- $\mathrm{TiO}_{2}$. The optimal amount of micro- $\mathrm{TiO}_{2}$ was $9 \%$, which removed $98.25 \%$ of the color; the optimal amount of nano- $\mathrm{TiO}_{2}$ was $3 \%$, which removed $89 \%$ of the color. Figure 3 shows the color degradation for $9 \%$ micro$\mathrm{TiO}_{2}$, and Figure 4 shows it for $3 \%$ nano- $-\mathrm{TiO}_{2}$. Overall, results indicate that nano-and microscale $\mathrm{TiO}_{2}$-infused concrete may be able to remove organic pollutants that come in contact with the concrete surface.

Figure 5 charts the color removal efficiency of all the micro- $\mathrm{TiO}_{2}$ concentrations, clearly showing $9 \%$ to be the optimal amount. Figure 6 charts the same for all nano- $\mathrm{TiO}_{2}$ concentrations, indicating the optimal amount to be $3 \%$. Figure 7 shows the color intensity degradation caused

\begin{tabular}{|c|c|}
\hline Sieve Size & \% Passing as tested \\
\hline $3 / 8$ inch $(9.5 \mathrm{~mm})$ & 100 \\
\hline$\# 4(4.75 \mathrm{~mm})$ & 97 \\
\hline$\# 8(2.36 \mathrm{~mm})$ & 86 \\
\hline$\# 16(1.18 \mathrm{~mm})$ & 80 \\
\hline$\# 30(600$ micro meter $)$ & 45 \\
\hline$\# 50(300$ micro meter $)$ & 13 \\
\hline$\# 100(150$ micro meter $)$ & 0.5 \\
\hline
\end{tabular}

Table 3: Fine aggregate gradation (Information provided by Jeffery Sand Co).

\begin{tabular}{|c|c|c|}
\hline & Nano & Micro \\
\hline $\mathrm{TiO}_{2}$ (Weight)\% & 99.7 & 97.5 \\
\hline Type of crystal structure & Anatase & Anatase \\
\hline Particles size & $\leq 25 \mathrm{~nm}$ & $\leq 850 \mu \mathrm{m}$ \\
\hline
\end{tabular}

Table 4: Nano- and micro- $\mathrm{TiO}_{2}$ characteristics (Information provided by Crystal Co and Sigma-Aldrich).

\begin{tabular}{|c|c|c|c|c|c|}
\hline Material (gm) & $\mathbf{3} \% \mathrm{TiO}_{\mathbf{2}}$ & $\mathbf{6 \%} \mathrm{TiO}_{\mathbf{2}}$ & $\mathbf{9 \%} \mathbf{T i O}_{2}$ & $\mathbf{1 2} \% \mathrm{TiO}_{\mathbf{2}}$ & $\mathbf{1 5 \%} \mathbf{~ T i O}_{\mathbf{2}}$ \\
\hline Cement & 8.73 & 8.46 & 8.19 & 7.92 & 7.65 \\
\hline Fine aggregate & 25 & 25 & 25 & 25 & 25 \\
\hline Coarse aggregate & 12 & 12 & 12 & 12 & 12 \\
\hline Water & 5 & 5 & 5 & 5 & 5 \\
\hline $\mathrm{TiO}_{2}$ & 0.27 & 0.54 & 0.81 & 1.08 & 1.35 \\
\hline
\end{tabular}

Table 5: Components of the different concrete mixes used in this study. 
Citation: Elia HN, Ghosh A, Akhnoukh AK, Nima ZA (2018) Using Nano- and Micro-Titanium Dioxide $\left(\mathrm{TiO}_{2}\right)$ in Concrete to Reduce Air Pollution. J Nanomed Nanotechnol 9: 505. doi: 10.4172/2157-7439.1000505

Page 4 of 5

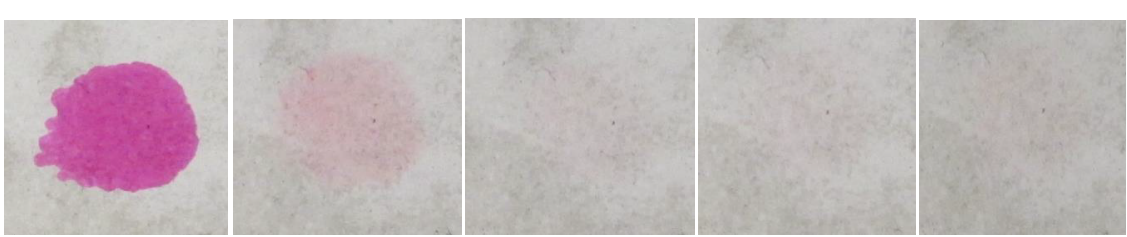

Figure 3: $9 \%$ micro- $\mathrm{TiO}_{2}$ at $0,24,48,72$, and 96 hours (left to right)

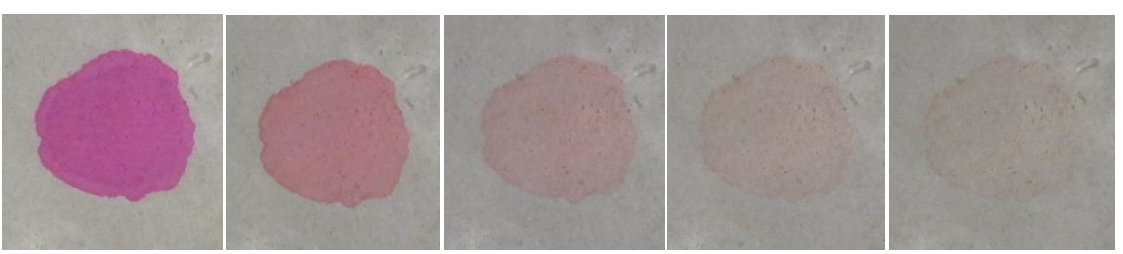

Figure 4: $3 \%$ nano- $\mathrm{TiO}_{2}$ at $0,24,48,72$, and 96 hours (left to right).

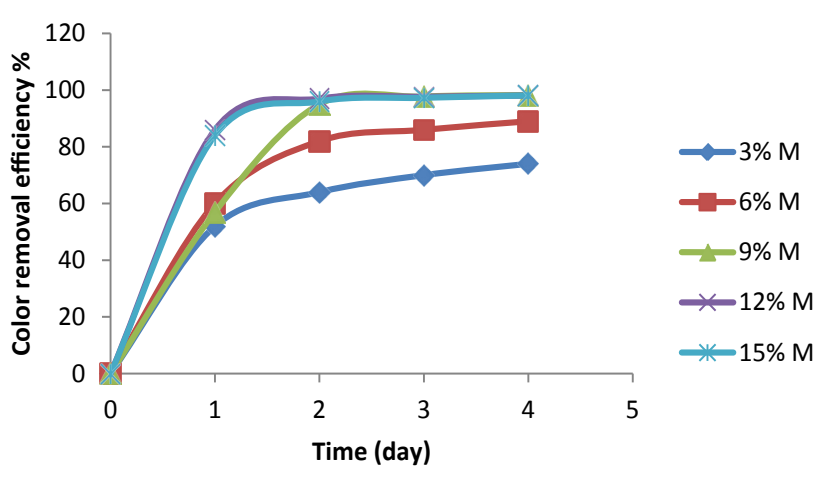

Figure 5: Color removal efficiency of all micro- $\mathrm{TiO}_{2}$ concentrations with time (day).

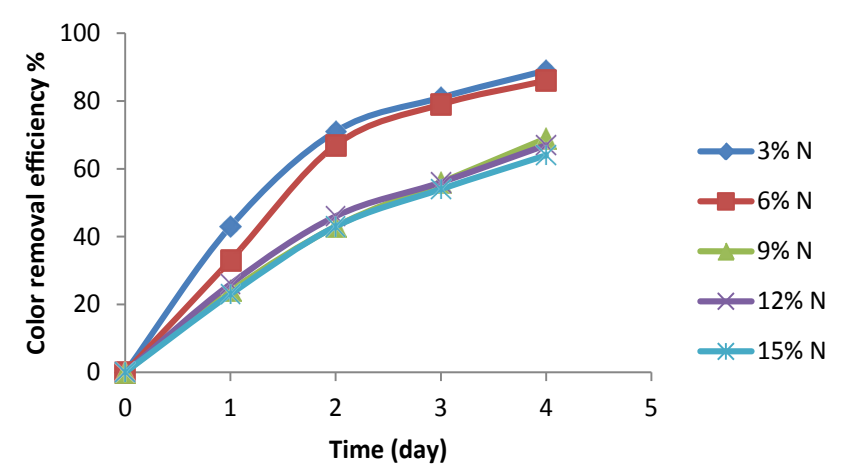

Figure 6: Color removal efficiency of nano-TiO ${ }_{2}$ over time (day).

by nanoscale $\mathrm{TiO}_{2}$, and Figure 8 shows the color intensity degradation caused by microscale $\mathrm{TiO}_{2}$.

\section{Conclusion}

Studies have shown that titanium dioxide helps produce a concrete that can clean itself and the air around it by various mechanics, particularly photocatalysis. To evaluate this concept, we measured the pollutant removal efficiency of $\mathrm{TiO}_{2}$ by applying Rhodamine $\mathrm{B}$ dye on the surface of $\mathrm{TiO}_{2}$-infused concrete mixes and calculating the surface's

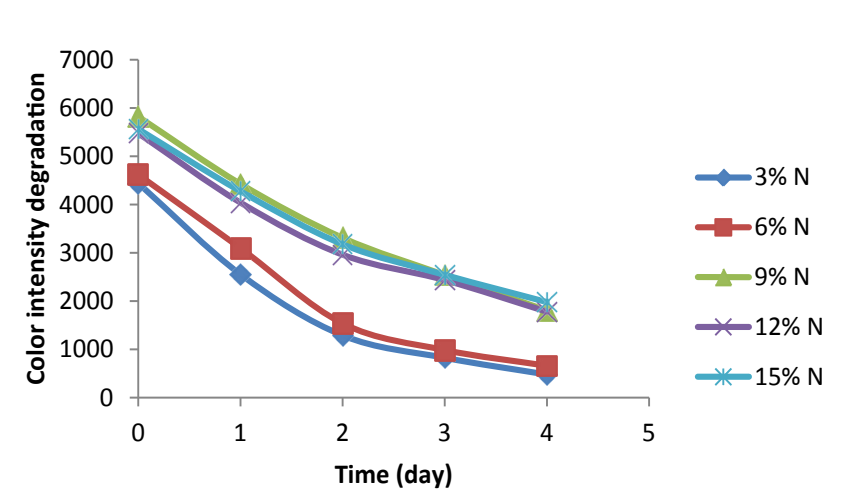

Figure 7: Color intensity degradation by nano- $\mathrm{TiO}_{2}$ over time (day).

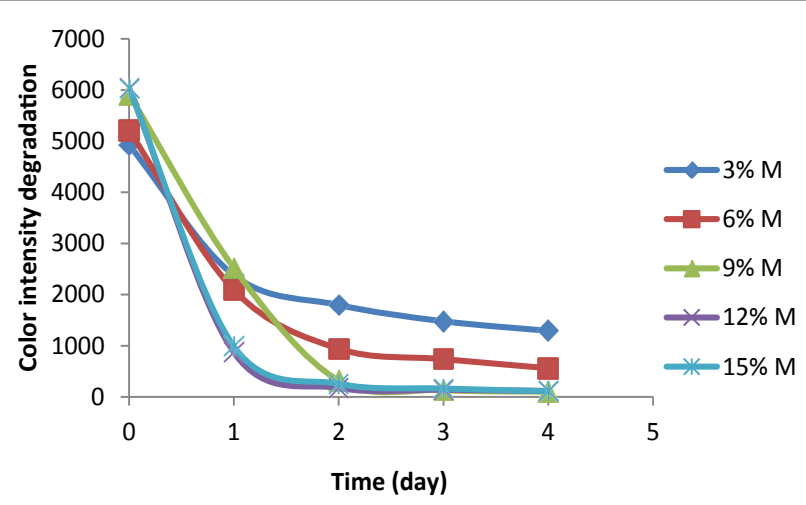

Figure 8: Color intensity degradation by micro- $-\mathrm{TiO}_{2}$ over time (day).

removal efficiency, which represents its potential removal efficiency of air pollutants and certain organic contaminants. Our results indicated that both nano- and micro- $\mathrm{TiO}_{2}$-infused concrete can remove organic pollutants that interact with concrete's surface. Microscale $\mathrm{TiO}_{2}$ showed more efficient color removal than the nanoscale samples. The optimal dose of microscale $\mathrm{TiO}_{2}$ was $9 \%$ of the cement concentration, with its color removal efficiency reaching up to $98.25 \%$. The optimal dose of nanoscale $\mathrm{TiO}_{2}$ was $3 \%$ of the cement concentration, having color removal efficiency of $89 \%$. Therefore, our study clearly shows 
Citation: Elia HN, Ghosh A, Akhnoukh AK, Nima ZA (2018) Using Nano- and Micro-Titanium Dioxide $\left(\mathrm{TiO}_{2}\right)$ in Concrete to Reduce Air Pollution. J Nanomed Nanotechnol 9: 505. doi: 10.4172/2157-7439.1000505

Page 5 of 5

that mixing small amounts of $\mathrm{TiO}_{2}$ (either nano-or micro- size) into cement mixtures can have drastic effects on the overall ability of the resulting concrete to remove pollutants and self-clean. In the future, we will investigate other photocatalytic active agents in order to further optimize the photoactivity of cement.

\section{Acknowledgments}

We acknowledge partial support from the Center for Advanced Surface Engineering, under the National Science Foundation Grant No. IIA-1457888 and the Arkansas EPSCoR Program, ASSET III.

\section{References}

1. http://www.wbcsdcement.org/index.php/about-cement/benefits-of-concrete

2. Gaudette P, Slaton D (2007) Preservation of Historic Concrete"; National Park Service U.S. Department of the Interior. Heritage Preservation Services.

3. Chen B, Kan H (2008) Air Pollution and Population Health: A Global Challenge. Environ Health Prev Med 13: 94-101.

4. https://www.nature.nps.gov/air/aqbasics/sources.cfm

5. Weir A, Westerhoff P, Fabricius L, Von Goetz N (2012) Titanium Dioxide Nanoparticles in Food and Personal Care Products. Environmental Science Technology 46: 2242-2250.

6. Filipponi L, Sutherland D (2012) Nanotechnologies: Principles, Applications, Implications and Hands-on Activities.

7. Znaidi L, Seraphimova R, Bocquet J, Colbeau-Justin C, Pommier C (2001) Continuous Process for the Synthesis of Nanosize TiO2 Powders and Their Use as Photocatalysts. Material Research Bulletin 36: 811-825.
8. Bilmes S, Mandelbaum P, Alvarez F, Victoria N (2000) Surface and Electronic Structure of Titanium Dioxide Photocatalyst. J Physical Chem B 104: 9851 9858.

9. http://www.nano-zone.net/faq.php

10. Beeldens A (2006) An Environmentally Friendly Solution for Air Purification and Self Cleaning Effect: the Application of $\mathrm{TiO}_{2}$ as Photocatalyst in Concrete. Proceedings of Transport Research Arena Europe - TRA, Göteborg, Sweden.

11. Akbari H, Berdahl P (2008) Evaluation of Titanium Dioxide as a Photocatalyst for Removing Air Pollutants. California Energy Commission, PIER EnergyRelated Environmental Research Program.

12. Sazavska T, Subrt J, Jakubickova M, Peterka F (2015) Photocatalytic CoatingsPromising Way to Improve a Quality of Urban Building Surfaces. Chem Didact Ecol Metro 20: 113-122.

13. Kumar A, Kishu N (2016) Effect of Silica Fume and Fly Ash as Partial Replacement of Cement on Strength of Concrete. Inter J Innovative Research in Science, Engineering and Technology.

14. Dylla H, Mohammad L, Rupnow T, Wright E (2010) Evaluation of Environmental Transportation Research Record 46-51.

15. Zhang M, Tanadi D, Li W (2010) Effect of Photocatalyst TiO2 on Workability Strength, and Self-Cleaning Efficiency of Mortars for Applications in Tropical Environment. $35^{\text {th }}$ Conference on Our World in Concrete and Structures, Singapora.

16. Hassan MM, Dylla H, Mohammad LN, Rupnow T (1997) Methods for the Application of Titanium Dioxide Coatings to Concrete Pavement. Int J Pavement Res Technol 5: 12-20. 